This is an Accepted Manuscript of an article published by Taylor \& Francis in Journal of Environmental Planning and Management on 10 April 2018, available online: http://

www.tandfonline.com/10.1080/09640568.2018.1450230 


\title{
Meaning work: Reworking institutional meanings for environmental governance
}

\author{
Effective environmental governance requires institutional change. While some \\ actors work to change institutions, others resist change by defending and \\ maintaining institutions. Much of this institutional work is 'meaning work', \\ which we define as the practice of crafting, adapting, connecting and performing \\ meanings to purposively create, maintain or disrupt institutions. This paper \\ constructs a concept of meaning work that highlights agency in carrying \\ meanings across scales and between discursive layers, while noting the \\ structuring role of prevailing discourses. It grounds the concept using two \\ environmental governance cases at very different scales: a local democratic \\ innovation employed by Noosa Council in Queensland, Australia; and the \\ international campaign to divest from fossil fuels. The cases demonstrate the \\ diversity of meaning work and the difficulty of achieving deep discursive change. \\ They point to the need for environmental governance practitioners to rework \\ existing meanings to construct compelling stories for change, taking advantage of \\ narrative openings.
}

Keywords: Environmental governance; institutional work; institutional meanings; narrative; discourse

\section{Introduction: Institutional meanings and environmental governance}

The intensely political nature of transitions towards sustainability has prompted a flourishing of scholarly and practitioner interest in environmental governance (Patterson et al. 2017; Biermann 2007; Chaffin et al. 2016). Governance is "the ways and means employed by society to make collective decisions, choose collective goals, and take action to achieve those goals" (Chaffin et al. 2016, 401). Making collective progress on environmental problems has challenged human society for decades and effective environmental governance practices remain unclear in many domains.

An institutional perspective is an attractive lens to apply to the challenge of environmental governance. Institutions “comprise regulative, normative, and cultural- 
cognitive elements that, together with associated activities and resources, provide stability and meaning to social life" (Scott 2014, 56). As stable, resilient social and political structures, institutions can protect existing progress towards effective environmental governance but may also resist necessary further progress. This helps to explain why progress towards sustainability is widely regarded as slow. However, institutions do change, and institutional scholars have learned much about how institutions change. Insights from this literature have only recently begun to influence environmental governance theory and practice (Beunen and Patterson 2016). This special issue applies an established concept from the institutional change literature institutional work - to the challenge of environmental governance.

Institutional work is "the purposive action of individuals and organizations aimed at creating, maintaining and disrupting institutions" (Lawrence and Suddaby 2006, 215). It is a distinctive contribution within institutional theory because it places "the spotlight on the role of actors and their efforts to interact with and influence institutions" (Hampel, Lawrence, and Tracey 2017, 559). This makes it highly relevant for exploring how actors can respond to environmental challenges. The concept reminds us that "work" is required not only to create and challenge institutions, but also to actively maintain and defend existing institutions. Thus, while institutions are indeed stable and resilient, actors must apply effort to maintain institutions in something like their current form. The transition towards effective environmental governance requires both the defence of positive institutional gains and pressing forward against active resistance from actors that work to maintain problematic aspects of existing institutions. This sheds further light on our slow collective progress on environmental challenges.

Institutional work is diverse. Scott's (2014) definition of institutions above identifies regulative, normative and cultural-cognitive elements of institutions; 
institutional work includes work to create, maintain or disrupt any of these elements. Likewise, it includes work on the activities associated with institutions and the resources that support them. In this paper, we concentrate on work done on the immaterial elements of institutions. Institutional theorists use a multitude of terms to refer to these immaterial components, including normative and cultural-cognitive elements (Scott 2014), narratives and stories (Lowndes and Roberts 2013), story-lines and discourses (Hajer 1995), culture, myth and text (Zilber 2017). They are the meanings that underpin institutions - their ideational and symbolic components - as opposed to their material components (Zilber 2017).

Environmental governance scholars are cognizant of the role that meanings play in effective governance. The highly influential Earth System Governance Project - the largest social science network on global environmental governance - identified "norms, values and broader ideational structures" as one of four crosscutting themes guiding its research agenda (Biermann et al. 2009, 72). However, work undertaken in response to this research agenda has not applied the concept of institutional work, and this presents new opportunities, including the possibility of a more agentic and transformational approach to institutional change for environmental governance (Beunen and Patterson 2016). At the same time, institutional theorists have called for the concept of institutional work to be applied to pressing real-world challenges (Hampel, Lawrence, and Tracey 2017), of which the field of environmental governance has many.

Our paper develops the idea of institutional work on meanings as a way of improving the effectiveness of environmental governance. We start by constructing the concept of 'meaning work' for environmental governance, drawing on scholarship on meanings in institutional theory. We then test the value of the concept of meaning work by applying it to two environmental governance case studies. We chose these cases 
because both involve "institutions that matter" (Hampel, Lawrence, and Tracey 2017) for global environmental and social challenges, but their differing scales provide different insights.

The first case considers the institution of democratic decision-making at the scale of an Australian local government. The second considers the impact of the global fossil fuel divestment movement on institutional patterns of investment at a global scale. Our aims are: to test the ability of the concept of meaning work to deliver insights for environmental governance; to explore how meaning work varies with scale and other dimensions; and to identify ways in which actors can more consciously and effectively engage in meaning work for environmental governance.

\section{Meaning work for environmental governance}

To construct the concept of 'meaning work' for environmental governance, we start with a brief review of previous work on meanings in institutional theory, before focusing in on what makes the concept of institutional work distinctive.

\section{Meanings in institutional theory}

In a recent review, Zilber (2017) shows that institutional theorists have long been concerned with the role of meanings in institutions, at least since the emergence of neoinstitutional thinking in the 1970s. This interest in meanings coincides with a broader "narrative turn" in the social sciences (Polletta et al. 2011). Despite this long history, there are no agreed definitions of meaning in institutional theory (Zilber 2017) and terminological diversity abounds. We follow Zilber $(2017,419)$ by using meaning as a broad term that captures "those aspects of institutions that are ideational and at times even symbolic, to distinguish them from the material aspects of institutions, like structures and practices". 
Under this broad banner of institutional meanings, we find work on stories and storytelling (Polletta et al. 2011), narrative (Lowndes and Roberts 2013), cultural entrepreneurship (David, Sine, and Serra 2017; Lounsbury and Glynn 2001), organizational myths (Meyer and Rowan 1977), symbols (David, Sine, and Serra 2017), theorization (Strang and Meyer 1993) and discourse (Hajer 1995; Phillips, Lawrence, and Hardy 2004). Some of these terms are used interchangeably, while others denote specific types or theoretical constructions of meaning. For example, Polletta et al. (2011) choose to use the terms story and narrative interchangeably, but position discourse as a broader term that includes stories alongside other linguistic forms, such as arguments and rhetoric. Our purpose here is not to untangle this complex web of terminology but to move forward with a broad and inclusive concept of meanings in institutions.

Institutional theorists have considered how actors work with institutional meanings in some detail. Individual actors construct stories, storylines, narratives, organizational symbols or theorized accounts as a way of simplifying, reducing uncertainty, persuading, and making sense of the world (Zilber 2017; Lounsbury and Glynn 2001; Strang and Meyer 1993; Hajer 1995; Lowndes and Roberts 2013). They use these accounts to achieve their goals, recruit others to their cause (Fligstein and McAdam 2012; Hajer 1995) and act as cultural entrepreneurs (Lounsbury and Glynn 2001). They make choices to organize narratives in particular ways to suit the ends they seek (Czarniawska 2014). These choices are made within a discursive context that enables and constrains the stories they create (Hajer 1995; Healey 1999). Viewed from this perspective, environmental governance is a discursive struggle, or political contestation of meanings, as much as a material struggle. 
The literature on meanings in institutional theory makes two important distinctions that will inform our case analysis later in the paper. First is the distinction between story and storyteller, or between text and performance. We can analyze meanings as objects - stories, narratives, texts, symbols or discourses - or we can analyze the act of performing, constructing or reworking meanings - storytelling, narration, theorization, cultural entrepreneurship, or discourse structuration. Our interest here is in the work that actors are doing with meanings but we share sufficient story content to make the context for this meaning work clear.

Second is Healey's $(1999 ; 2003)$ argument that there are three levels of discourse, or layers of meaning, that constitute increasingly powerful sources of institutional change. Similar arguments have been made by other post-structural thinkers (Inayatullah 1998). At the surface are visible and transparent meanings, where there is "continual play with new metaphors and turns of phrase" (Healey 1999, 28). Changes in surface rhetoric may not penetrate to the second level, where 'more powerful discourse...generates a system of meaning about an area of policy" or to the third level of "deeper...cultural reference points" (Healey 1999, 28). Discursive struggles often take place in the surface layer without prompting deeper institutional change. In analyzing meaning work, we aim to clarify:

how much of the struggling is merely ripples on the surface of a settled modality of governance, what is shifting the parameters of established discourse and practice relations, and what is unsettling the whole culture of governance relations (Healey et al. 2003, 67).

Additional analytical concepts emerge from looking at the specific concept of institutional work. 


\section{Institutional work, and meaning work}

Institutional work is "the purposive action of individuals and organizations aimed at creating, maintaining and disrupting institutions" (Lawrence and Suddaby 2006, 215). It is a distinct approach within institutional theory, and one of particular interest for environmental governance, because it places "the spotlight on the role of actors and their efforts to interact with and influence institutions" (Hampel, Lawrence, and Tracey 2017, 559; Zilber 2017).

As Zilber $(2017,433)$ points out, much of the institutional work that actors do involves working with meaning or language. Institutional work includes "composing legislation, telling stories, writing histories, making jokes and insults, writing memos and letters, writing legal opinions, writing and making speeches and making announcements" (Lawrence and Suddaby 2006, 239). Institutional workers create new institutions by constructing collective identities, theorising and defining the relationships between actors and fields. They maintain institutions by valorising institutional content and demonising disruptive elements, as well as building and sustaining organisational myths, symbols and rituals. They disrupt institutions by undermining institutionalised assumptions and beliefs and decreasing the perceived risks of innovation and change (Lawrence and Suddaby 2006; Zilber 2017). Previous scholarship on institutional work highlights two additional analytical elements for us to examine in our cases.

First, a key theoretical foundation of institutional work is the idea of embedded agency (Hampel, Lawrence, and Tracey 2017; Battilana and D'Aunno 2009). Hampel, Lawrence and Tracey $(2017,559)$ summarise:

From an institutional work perspective, institutions shape every facet of human existence, providing meaning and motivation to our actions, and holding together 
the material and symbolic structures that trigger and shape those actions; at the same time, however, institutions are ongoing human accomplishments, constructed and maintained by people's behaviour, thoughts and feelings.

This is, of course, the well-known distinction between social actors (agents) and social structure as the key analytical element of the social sciences, which Giddens (1984) sought to resolve through his theory of structuration.

In analysing our cases, we need to be sensitive to the interplay between agency and structure as it relates to meaning work. The actors in our cases are agents that can shape reality through their meaning work, by choosing to tell particular stories, organising narratives in particular ways, framing, and creating symbols. At the same time, actors do their meaning work in a discursive context that constrains and enables their agency (Hajer 1995). This discursive context gives them access to particular meanings but not others and gives greater cultural weight to particular constructions of meaning. This orients our analysis towards the social practices of meaning work, since theories of practice provide a conceptual bridge between agency and structure (Giddens 1984; Shove, Pantzar, and Watson 2012; Hampel, Lawrence, and Tracey 2017).

The second analytical element to attend to is how meanings move across scales. Perkmann and Spicer (2008) examine cultural work as one form of institutional work. They note that cultural work "establishes or reframes belief systems and values, often by linking practices with more widely anchored discourses" (Perkmann and Spicer 2008, 813). These "more widely anchored discourses" may operate at different scales. For example, Zilber (2009) traced the movement of meanings from the broader institutional environment, to the organisational level, to their influence on individual life stories. At a societal scale, broad sociotechnical imaginaries (Jasanoff 2015) and metanarratives hold sway. Institutions and organisations have their own more specific narratives that draw on these broader meanings. Individuals have their own narratives or 
life stories that borrow from the institutions, organisations and groups they participate in. We anticipate that meaning work will look different at each scale and that an important part of meaning work is translation or adaptation between scales, connecting to familiar stories, frames and symbols that help people to make sense of the world, for example through use of metaphor. In our cases, we will seek examples of flow of meanings across scales.

We define meaning work, then, as the practice of crafting, adapting, connecting and performing ideational and symbolic resources such as stories, narratives, symbols, myths and discourses to purposively create, maintain and disrupt institutions. As discussed above, meaning work is a practice that is performed but becomes evident through textual artefacts. It is agentic, but constrained and enabled by discursive context. It involves movement of meanings across scales and penetration of meanings to varying levels of cultural depth. We now briefly discuss our methods for identifying and analysing meaning work, before turning to the cases.

\section{Methods}

Our two cases were chosen with the above distinctions in mind. We wanted to examine cases at different scales, with different discursive contexts, to see how meaning work differs with scale and context. The first case, a citizen jury on management of the Noosa River, operates at the scale of a small local government. It was the first attempt to bring this kind of democratic innovation to the Australian state of Queensland, and therefore a likely site of discursive contestation. The second case, on fossil fuel divestment, is a global environmental movement that has purposively sought to reshape meanings about climate change in an attempt to bring about more effective governance responses.

Given the performative character of meaning work, observation is arguably the best method to study meaning work. However, observation is time-intensive, costly and 
risky (as there is no guarantee that interesting meaning work will be apparent). Instead, we drew on a combination of interviews and archival documents to reconstruct meaning work, focusing on cases where interesting meaning work seemed likely. For the Noosa case, we drew on interviews with the organisers of the citizen juries, supplemented by documentary evidence, to explore the very local meaning work done in Noosa. We asked interview participants about their motivations and interests in relation to the juries to reconstruct, as much as possible, the meaning work they were doing. For the fossil fuel divestment case, we draw entirely on literature and archival material about the movement to investigate meaning work at the distinctly different scale of international environmental narratives.

While imperfect, the reflective nature of interviews, and their timing, meant that we were able to elicit key meanings that had solidified to the extent that they were repeated, often with very similar phrasing, by different interview participants (and in different documents). Our analysis of the interview data and documents started with a grounded approach that allowed codes and categories to emerge, before connecting the emerging categories with the concepts outlined above from institutional theory. Consistent with our aims, we were particularly sensitive to the power of meaning work in explaining the outcomes of the cases, variations of meaning work, and strategies for effective meaning work in the realm of environmental governance. 


\section{Democratic innovation for river management in Noosa}

\section{The Noosa River Community Jury}

In 2015, Noosa Shire Council (NSC) ${ }^{1}$ in Queensland, Australia partnered with the newDemocracy Foundation (NDF) ${ }^{2}$ to hold two citizen juries on local environmental issues. These local democratic innovations brought together randomly selected citizens from the Noosa area to deliberate on two topics: local waste management; and management of the Noosa River. Our focus is on the second jury, which addressed the topic: "How can we manage the Noosa River better? What role should Council play and what resources should Council apply?"

The citizen jury comprised 26 citizens. NDF sent out 3,000 invitations at random to Noosa residents, and chose the final jury from the 223 that responded, selecting from this group at random to approximate the demographic profile of Noosa. The jury met five times between August and December 2015 to consider the questions listed above. It made 12 recommendations to NSC, and presented a majority (but not consensus) view that:

${ }^{1}$ NSC is one of 77 local governments in the Australian state of Queensland, governing an area of $871 \mathrm{~km}^{2}$ on the Sunshine Coast, north of Brisbane. It has a population of about 56,000.

${ }^{2}$ The newDemocracy Foundation is "an independent, non-partisan research and development organisation" focused on democratic innovation. It aims "to discover, develop, demonstrate, and popularise complementary alternatives which will restore trust in public decision making". It conducts "real world trials using random selection and deliberation the jury model - as a central process" (newDemocracy website, accessed $4^{\text {th }}$ December 2017). 
Council should take over the authority and finances from the State Government for managing anchoring, mooring, living on board and commercial use of the river on the basis it would be a user pays system funded through alternative means to rates.

To draw out the meaning work in this case, it is first necessary to set the scene.

\section{The institutional context}

Australia has three levels of government: a federal government with broad national powers; eight state and territory governments with geographically-bounded power over issues not under federal jurisdiction; and numerous local governments established under state legislation to govern local issues. Typically, the issues for which local governments are responsible include planning and building regulations, waste management, local roads, and local infrastructure.

NSC is a local government established by the Queensland Government (a state government) in 1910. Noosa is a popular holiday and retirement destination, located on the Noosa River where it joins the sea. In 2007, the Queensland Government established a Local Government Reform Commission, which recommended amalgamation of many smaller local governments across Queensland. Despite strong opposition from some local governments and residents, NSC merged with the neighbouring City of Caloundra and the Shire of Maroochy to form a new Sunshine Coast Council in 2008. A grassroots campaign for de-amalgamation subsequently gathered momentum, with the former Mayor of NSC playing a key role through the Noosa Independence Alliance. This campaign led to the Queensland Government giving residents the opportunity to vote for de-amalgamation in 2013. More than $80 \%$ of Noosa residents voted for deamalgamation, and NSC recommenced on 1 January 2014, with the former Mayor elected as Mayor of the new Council. The new NSC committed to hold citizen juries in late 2014 and held the two juries during 2015. The sections below explore different 
dimensions of the meaning work that was evident during the establishment, implementation and follow up of the juries.

\section{Tapping into an existing story-line}

A story-line is a shared narrative on social reality that provides actors with a common set of meanings to draw on, and binds together discourse-coalitions (Hajer 1995, 62). As a consequence of the political history outlined above, a shared story-line and identity were evident in Noosa. Through seven years of grassroots campaigning, Noosa residents had rallied around a story-line in which local government is closely connected to local residents and responsive to local needs. An important component meaning was that Noosa residents should make decisions about what happens in Noosa. The Chief Executive Officer (CEO) of Noosa Council expressed the story-line succinctly as "local people wanted a local say on local issues".

After the success of the de-amalgamation campaign, actors could draw on this established story-line to do institutional work, but it also constrained what was politically acceptable. During the de-amalgamation campaign and the subsequent NSC elections, the former Mayor campaigned successfully on the importance of residents having a say in how their local community was governed. He was conscious of the need for the re-established institution to align with the established story-line:

They've [Noosa residents] been used to having a say. They've been used to being listened to by Noosa Council because that's the way Noosa Council operated before it was amalgamated in 2008. When we de-amalgamated, I was determined that, and so were the whole Council, that we would do everything we possibly could to make sure the community felt they were listened to and they could have a say on any issue they want to (Mayor, NSC, 2014-16).

The staff and elected representatives responsible for rebuilding NSC as an institution 
after the process of amalgamation and de-amalgamation needed to keep a mobilised community on-side. New institutions can be fragile and there was a real risk of backlash if the new NSC failed to deliver on its promise to give the community a voice. Key actors needed to show good faith by doing something innovative and the juries became the natural culmination of the de-amalgamation story-line:

[The Community Jury] actually took that local people having a local say on local issues to its natural conclusion...The way we got it over the line was this whole context of the de-amalgamation journey. We've got a community that's engaged, we've got a community that demands engagement and this is the logical jump (CEO, NSC).

The community jury was a symbolic gesture towards the Noosa community that this council wants to engage (Current Mayor, NSC).

The juries neatly tapped into the established story-line of "local people having a local say on local issues" and helped to build the credibility of the new institution. The interplay of agency and structure in meaning work is evident here. On the one hand, NSC actors cleverly tapped into an existing story-line to maintain the legitimacy and authority of a new institution. Indeed, they were able to act as cultural entrepreneurs, using the story-line to make something very innovative seem like a natural progression. No Queensland local government had ever used a citizen jury in decision-making, yet NSC actors were able to "get it over the line" by positioning it as a "natural conclusion". On the other hand, Noosa residents would have no doubt rebelled if the established story-line they had fought so hard for had not been honoured with some kind of innovative approach to community engagement.

\section{Discursive struggle across governance scales}

We also found evidence of NSC actors using the citizen jury to do symbolic work in a 
discursive struggle across governance scales. Management of the Noosa River is primarily the responsibility of the Queensland Government. Noosa residents are affected by decisions made about the river, but have few direct avenues to influence those decisions. This conflicts with the story-line discussed above - Noosa residents felt that they should have a say over how "their" river is managed. However, winning additional powers for river management from the Queensland Government would be a difficult political struggle. Senior figures in NSC recognised the symbolic role that a citizen jury could play in giving them authority to engage in that struggle: As the Mayor (2014-2016) put it, the jury gave NSC:

more authority. Not legal authority, but moral authority, in convincing the state that this is really a local issue, and the local community wants to look after it. The state knows that they're not looking after it properly, they know that. There are signs that they will be willing to go down this route. But they require really significant consultation with the community before they make a decision, and the community jury has been, I think, a really important element of that.

The CEO told a similar story:

It has an indirect value which should not be a reason for doing a jury. The indirect reason is that it gives a difficult council decision a bit of political capital. If you use that as a reason to do a jury, it's the wrong reason to do it, but it's reality. We can say, "Well, the community asked us to do this, we're going to do it".

The jury became a symbolic resource that NSC could use to do the political work of making a case for institutional change to the Queensland Government. The outcome is not yet known but the jury provided NSC with an opening to at least start this political contest. 


\section{Accommodation of meanings}

Normally, many different actors will be trying to do meaning work simultaneously, resulting in contestation over meanings. While NSC was doing meaning work, NDF was attempting its own meaning work. Since 2011, NDF has worked with Australian governments to design and manage numerous citizen juries. NDF argues that existing representative political institutions fail to respond to the considered will of the people they are meant to serve. In the specific context of local government, residents elect Councillors to represent them and make decisions on local matters. There are opportunities for the community to provide input on decisions through Council meetings and submissions but these avenues are little used, those who use them are not representative of the wider community, and participants present their personal views without necessarily reflecting or deliberating on the public interest. NDF advocates citizen juries as a way to insert more deliberative and participatory forms of decisionmaking into Australia's institutions of representative democracy. At a local government scale, a citizen jury brings together a demographically representative group of citizens to consider the issue at hand, take time to deliberate on it together, and provide advice to the decision-makers. The idea is that the jury will draw out voices that are not normally heard and that the participants will reflect together on the issue, perhaps changing their views in response to evidence and perspectives presented during the jury.

As noted above, the de-amalgamation campaign established a story-line of "local democracy" that appeared to share core meanings with NDF's narrative of democratic innovation. This led NSC to approach NDF to explore the establishment of citizen juries as a way of "putting more decision making in the hands of the local community" (newDemocracy Foundation website, accessed December 4, 2017). The design document produced by NDF for the community juries in late 2014 foregrounds a 
narrative of democratic innovation and institutionalisation. It tapped into Noosa's strong local identity by aiming to "make Noosa Council a national and international leader in sharing decision-making power with the community" (newDemocracy Foundation 2014). The ambition of the document is clear from its title: "delivering Noosa Council a democratic process the envy of Australia". The proposal was to pilot the citizen jury approach to decision-making over an 18-month period with a view to institutionalising it as a routine form of community participation in important local decisions:

This paper outlines a structure, a set of principles and an outline of the first 18 months of operations which would constitute the pilot phase in order to assess its practicality...[What] is being pursued is new in the scale at which it is being considered: trial before embedding this as "how we do government" is entirely appropriate (newDemocracy Foundation 2014).

A September 2014 media release announcing the initiative was titled "Democracy - the Noosa way" (NSC website, accessed December 4, 2017. In that media release, quotes from the Mayor included him describing the jury as "innovative, genuine democracy" and confirming the relationship between this initiative and the de-amalgamation process: "In the de-amalgamation battle, our community was not just fighting for the return of their council, but also for a bigger say in local decision-making". The Executive Director of NDF described the juries as “a first for Queensland, and of national importance because it brings the practical and trusted democracy of the jury system inside the local decision-making process to a greater degree than anyone has previously attempted".

While the decision to establish the juries was initially propelled by a narrative of institutionalising local democratic reform, this narrative lost momentum as the juries progressed. After holding two juries, the normative aspiration to institutionalise juries as a regular decision-making mechanism faded, replaced by a more instrumental narrative: 
It's just one more tool in the toolbox (Mayor of NSC, 2014-2016).

It's a good tool in a toolbox, and you pull out that tool when you've got the right problem...It's the ultimate tool in terms of community empowerment...We shouldn't use it because we think we have to have a jury every six months, it doesn't suit everything (CEO, NSC).

These quotations reveal how the discourse had solidified to the extent that both the Mayor and CEO, in separate interviews conducted by different interviewers on different visits, used the phrase "tool in the toolbox" to refer to the juries. By the time of our interviews, the narrative around the community juries had shifted from one of leading Australian democratic reform and innovation by embedding juries as normal practice to a more cautious story of using juries occasionally for particularly difficult problems.

This narrative shift had numerous drivers, three of which are worth highlighting here. First, NSC had contracted NDF to deliver two citizen juries in a given time period. NSC found it difficult to choose a suitable topic for the second jury and ended up rushing the process to meet contractual requirements and avoid conflict with the timing of an upcoming election. This contributed to a more cautious view about institutionalising citizen juries. Second, the failure of the jury to reach consensus undermined NSC's initial belief that the process could deliver advice that was genuinely different from more conventional forms of community consultation, such as surveys. Third, NSC was more established by this point and perhaps felt less ongoing pressure to demonstrate innovative community engagement.

This is not meant to imply that there was no institutional change. While the initial zeal for democratic innovation faded, our interview participants all clearly stated that they would hold a citizen jury again when the right issue came along. In fact, we see the positioning of citizen juries as "one tool in the toolbox" of community engagement as a way of normalising them, incorporating them into the narrative of what 
local government does. From the perspective of meaning work, the innovations proposed by NDF were initially embraced by NSC as a way to establish its legitimacy and credibility in carrying the story-line of local democracy on. However, over time, what we observed was the more radical set of meanings carried by actors from NDF being gradually diluted through multiple discursive acts so that they could be accommodated into the institution of local government without a disruptive shift to a new institutional form. Innovative meanings were subordinated to a more conventional narrative that established NSC as the final decision maker and the arbiter of when juries would be used, and on what issues. This process was aided by rules governing the institution of local government. Interview participants reminded us several times that legislation does not allow Councils in Queensland to devolve final decision-making power to their communities.

This accommodation of potentially disruptive meanings is a form of institutional maintenance - weaving a narrative that brings in the new without too much disruption to the old. In Healey's (1999) terms, NDF's meanings changed the surface rhetoric in Noosa, had some impact on actual practice, but did not alter the deeper culture of governance in Noosa. On its first deployment in Queensland, the democratic reform narrative was not sufficiently well established to drive deeper cultural change. Many more successful juries across the state would likely be required before a narrative could build such power.

\section{Flow of meanings}

One final point to draw out is that flow of meanings in multiple directions was evident. Above, we related two examples where NSC drew on new meanings from its broader context - the community story-line of local democracy and NDF's narrative of democratic innovation. However, meanings also moved out from NSC. NSC staff 
carried the story of their innovation out into other contexts where their specific case could potentially influence broader narratives. For example, NSC staff had presented about the juries at several local government conferences and received much interest from other local government staff. Many other local governments in Australia are implementing democratic innovations and their specific local stories have the potential to weave together to create a broader narrative of democratic reform. To continue our exploration of meaning work for environmental governance, we move now from the local scale of Noosa to the much larger scale of the international campaign for fossil fuel divestment.

\section{The fossil fuel divestment movement}

The fossil fuel divestment movement is an interesting case for this paper because it has deployed a compelling narrative with enough rhetorical power to rapidly move around the globe and drive institutional change in diverse locations and contexts. Bill McKibben summarised the narrative in an article in Rolling Stone magazine:

The logic of divestment couldn't be simpler: if it's wrong to wreck the climate, it's wrong to profit from that wreckage. The fossil fuel industry ... has five times as much carbon in its reserves as even the most conservative governments on earth say is safe to burn - but on the current course, it will be burned, tanking the planet. The hope is that divestment is one way to weaken those companies - financially, but even more politically. If institutions like colleges and churches turn them into pariahs, their two-decade old chokehold on politics in DC and other capitals will start to slip (McKibben 2013).

Thus, the movement aims to: "shame, pressure, facilitate, and encourage investors...to divest their holdings of fossil fuel stocks in favour of other climate-friendly, or at least climate-neutral alternatives", thus appealing to "moral principles rather than economic self-interest" (Ayling and Gunningham 2015, 2). The movement challenges the 
institutional norm of investing in companies based solely on their financial performance, arguing that there is a moral imperative to also consider their impact on climate change. It seeks to delegitimize the institutions that profit from the status quo the complex web of fossil fuel companies and those who invest in them. It employs meanings that "stigmatize" the fossil fuel industry and create "a moral crisis" (Bratman et al. 2016). The movement is an intentional act of institutional wrecking that has become the fastest growing divestment movement in history (Ansar, Caldecott, and Tilbury 2013). Below, we define what is meant by fossil fuel divestment, provide a brief history of its development and status, and identify the types of meaning work evident in the case.

\section{Constructing a new narrative for climate change response}

After the 2009 United Nations Climate Change Conference in Copenhagen failed to deliver the fair, ambitious and binding treaty on climate change response that many activists had sought, action on climate change stalled. Climate activists around the world paused to reflect and develop new strategies. At Swarthmore College, Pennsylvania, a group of students used their 2010 spring break to visit activists who were opposing coal mining in Appalachia (Bratman et al. 2016). They discovered that Swarthmore had investments that supported coal mining. On their return, they demanded that Swarthmore remove its financial support for companies involved in fossil fuel production. In doing so, they launched a global divestment movement and birthed a new narrative for climate change response. Since then, more than 808 
institutions and over 58,000 individuals holding \$5.57 trillion in assets have divested ${ }^{3}$, although, ironically, Swarthmore College is not among them.

The construction of this new narrative for climate change response has been very visible and public, facilitating identification of some key stages in narrative construction. The narrative emerged when the students repurposed existing meanings to build a story-line that would meet their needs. They adopted divestment as a tactic having researched similar earlier campus movements in relation to apartheid and tobacco:

Fossil fuel divestment is meant to do to the carbon polluting industries like coal and oil what the South African divestment push did to the apartheid government thrust their practices into the spotlight, focus attention on the actors that profit from the status quo, and force moral re-evaluation, leading to shifts in political power (Bratman et al. 2016, 680).

The historical discourse on divestment became an origin story and enabling structure for the students as agents of a new story-line. It helped them to harness particular meanings into the narrative of the fossil fuel divestment movement, most notably ideas of morality and agency. The students recast investment choices as a moral decision, and positioned financial support for the companies that extract fossil fuels as immoral. They reframed the climate narrative to facilitate "deeper engagement with global justice concerns and underlying political economy that is influencing (and obstructing) the transition to a low carbon world" (Healy \& Debski 2017, 700-701). This was a rare rhetorical move at the time, with most activists focusing on how to reduce greenhouse gas emissions from fossil fuel consumption, rather than production. Bratman et al.

\footnotetext{
${ }^{3}$ As of $4^{\text {th }}$ December 2017, according to the Fossil Free website, https://gofossilfree.org/divestment/commitments/.
} 
(2016) describe how positioning divestment as a social justice cause broadened student interest and recruited students outside those with environmental interests (such as racial minority organisations) through a process of issue linkage to create a stronger and more diverse discourse coalition

At the same time, this rhetorical move gave agency to a much wider group of actors. Many find it difficult to see their role in responding to a global issue that has its roots deep in the structure of our techno-economic systems. The students made the case that we can all act by withdrawing our financial support from companies that produce fossil fuels. If we are not financially supporting such companies, we can put political pressure on those that do. These meanings, embedded in the narrative at its origin, became its foundation.

What is striking about this process of narrative construction is its accessibility. The students lacked the resources to directly influence fossil fuel investment and the power to change rules, but they had no shortage of imaginative and rhetorical resources to draw on. Anyone can tap into meanings that are already circulating to construct a narrative. In this case, the students planted the seeds of a narrative that would spread around the world.

\section{Sending the narrative global}

The initial narrative was powerful enough to spread to other campuses in the United States, but something more was needed to carry it from a local to a global scale. In 2012, prominent environmental activist Bill McKibben used an article in Rolling Stone magazine - Global Warming's Terrifying New Math - to popularise the fossil fuel divestment movement (McKibben 2012). McKibben did some skilful meaning work in the piece. First, he chose a prominent popular culture magazine to disseminate his message, to reach a broader audience. Second, he simplified the complexity of climate 
change. He introduced readers to three numbers: the globally agreed target to limit global warming to no more than $2^{\circ} \mathrm{C}$; the amount of carbon pollution that can be released into the atmosphere without breaching this limit (565 gigatonnes - the "carbon budget"); and the carbon that would be released if humanity burnt all of its known fossil fuel reserves (2,795 gigatonnes - five times the carbon budget). He urged readers to "do the math", arguing that $80 \%$ of all known fossil fuel reserves need to stay in the ground as "unburnable carbon" if we are to effectively respond to climate change (Carbon Tracker Initiative 2011; McKibben 2012). These rhetorical strategies cut through the complexity of climate change to reveal a simple truth: if humanity is serious about limiting global warming, we cannot burn more than a fraction of available fossil fuels. This was captured in the rallying cry of "keep it in the ground".

Third, he connected this "math" to the divestment movement and consciously created a villain:

A rapid transformative change would require building a movement, and movements require enemies.... And enemies are what climate change has lacked. Given this hard math, we need to view the fossil-fuel industry in a new light. It has become a rogue industry, reckless like no force on Earth. It is Public Enemy Number One to the survival of our planetary civilization (McKibben 2012).

Casting villains or antagonists is a classic rhetorical strategy to build legitimacy for institutional change (Ruebottom 2013; ACF 2017). As noted above, the divestment narrative also casts all of us as potential heroes who refuse to invest in fossil fuels. Thus, McKibben created a classic story structure (ACF 2017) in which a protagonist must overcome a moral challenge while resisted by an antagonist.

The meaning work that McKibben did is eloquently captured in the subtitle of his article: "Three simple numbers that add up to global catastrophe - and that make clear who the real enemy is". McKibben "packaged and popularised divestment by 
outlining the key figures and arguments in an easily digestible format, leading to its rapid mass diffusion" (Grady-Benson and Sarathy 2016, 665). His piece made the movement globally relevant by connecting divestment not to the local experiences of those affected by coal mining in Appalachia, but to a global carbon budget applying to us all. Suddenly, the narrative was relevant to all and poised to spread. McKibben personally supported the spread of the narrative by embarking on a Do the Math speaking tour, physically carrying meanings around the United States and into Australia and Europe during 2012 and 2013.

The fossil fuel divestment movement has since grown into an international movement supported by organisations like 350.org, which assists people to establish and grow local Fossil Free campaigns in their institutional context. In the United States, there are over a thousand campuses engaged in divestment campaigns and there have been some significant wins, such as Stanford University's commitment to divest (Grady-Benson and Sarathy 2016). The movement has spread beyond universities to also target financial institutions, charities, religious organisations, public institutions and individual investors.

\section{Discursive struggle}

In addition to framing fossil fuel companies as the villains, movement actors pointed out the riskiness of investing in fossil fuels due to the potential for a 'carbon bubble' (Gore \& Blood 2013) and stranded assets (Ansar et al. 2013) if current fossil fuel reserves need to stay in the ground. Movement actors did not expect to directly affect the financial viability of fossil fuel companies - after all, when someone divests, someone else is there to buy those assets. Instead, by altering the meaning of fossil fuel extraction they wanted to create uncertainty and "removal of fossil fuel companies' social licence to operate, through a process of reputational damage and stigmatisation" 
(Ayling and Gunningham 2015, 5).

Any movement seeking to so thoroughly undermine and disrupt the highlyprofitable institutional support for fossil fuel extraction was always going to meet considerable opposition. Well-endowed universities in the USA rejected divestment on grounds such as “cost”, "risk", "fiduciary responsibility” and perceived "minimal impact" (Healy and Debski 2017, 712-14). This is despite evidence that investment portfolios without fossil fuels can perform better than those with fossil fuels, as the Australian National University (ANU) discovered when they partially divested in 2014 (Gardner 2015). When an institution does divest, the discursive reaction from defenders of fossil fuel extraction can be strong and swift. ANU became the first Australian university to partially divest from fossil fuels when it divested from 7 holdings representing just $1 \%$ of its total investment fund and valued at about $\mathrm{A} \$ 16$ million (Jotzo 2014). Its decision to divest drew outrage from some of the companies involved on the grounds of unfairness and inaccuracy, a negative media campaign in the Australian Financial Review, and was openly criticised by the Australian Prime Minister and Treasurer as "removed from the reality of what is helping to drive the Australian economy and create more employment" (Jotzo 2014). One of the divested companies, Sandfire, followed up with legal action against the company that advised ANU. The ANU subsequently backed down, appointed a new independent portfolio adviser and reinvested in some of the divested companies.

Jotzo (2014) argues that the strong reaction may have been partly due to the symbolic power of the movement and its ability to "hit a strong nerve with the public". As the first university in Australia to divest, there was potential for others to follow suit and defenders of the status quo needed to strongly mobilise to maintain existing institutions. What is clear is that meaning work can face fierce opposition. Those 
promoting the divestment narrative enter a crowded narrative environment, where others are promoting narratives of climate denial, economic growth, and fiduciary responsibility. When discursive contestation is not enough, defenders of institutional stability may resort to regulative norms (rules) as Sandfire did in the ANU case.

\section{Just ripples on the surface?}

Given that divestment is primarily a symbolic act, and is fiercely resisted, many have questioned whether the movement can trigger genuine institutional change. Is it merely creating "ripples on the surface" or can it unsettle deeper governance relations (Healey et al. 2003)? If we focus on resources, materials or rules, the changes prompted by the divestment movement appear incremental rather than transformational. Although the divestment movement quotes large figures like $\$ 5.57$ trillion $^{4}$, this gives a misleading impact of the resources affected by the movement, as it is actually just the sum of the assets held by organisations that have divested. Actual impacts on the market value of fossil fuel companies and their ability to go about their business are hard to find and likely small.

However, this misses the point. The goal of the movement is to stigmatise fossil fuels and make it difficult for new fossil fuel projects to get started. Here, there are signs that the movement is having a deeper discursive and institutional impact. For example, the Indian-owned company Adani is developing the massive Carmichael Coal Project in the Australian state of Queensland. Campaigners against the mine draw heavily on the narrative of divestment and the argument that fossil fuels need to stay in the ground. Adani has been unable to secure finance for the mine and Australia's big

\footnotetext{
${ }^{4}$ https://gofossilfree.org/divestment/commitments/, $4^{\text {th }}$ December 2017.
} 
four banks have ruled out investing in the mine under pressure from activists, while the Reserve Bank of Australia has warned of the risk of stranded assets (The Sydney Morning Herald, August 11, 2017). When conservative institutions like these are changing their investment practices and advice it is fair to say that the divestment narrative is affecting systems of meaning about investment policy.

Nevertheless, it is important not to overstate the impact of the movement. In the higher education sector, institutions that have divested tend to be the smaller ones, with smaller endowments (Healy and Debski 2017). Globally, investment in fossil fuels continues, albeit at a slower rate than in the past (Hirtenstein 2017). Perhaps most importantly, the fossil fuel divestment movement does not fundamentally question deeper governance relations. It works within the institutional logic of capital investment rather than seeking fundamental structural changes to the economic system, such as a shift to a post-growth economy (Jackson 2009). This can be seen as a strength, as it allows the movement to challenge prevailing investment discourse without being dismissed as too radical. For movement actors engaged in meaning work, the challenge is to strike a balance between having their meanings heard while providing enough provocation to drive change.

\section{Discussion: Meaning work in the cases}

Our cases demonstrate some of the diversity and complexity of meaning work in two different contexts, and at two different scales. Meaning work was done to satisfy both normative and instrumental motivations, to build and defend new institutions, and to undermine existing institutions. Our definition of meaning work aims to capture this diversity: meaning work involves crafting, adapting, connecting and performing ideational and symbolic resources to purposively create, maintain or disrupt institutions. Crafting was evident when actors created new symbols or expressions of meaning, such 
as narratives of "unburnable carbon" and "keeping fossil fuels in the ground". We saw actors adapting, translating or rewriting existing meanings for new ends, for example when actors in Noosa used a narrative of local democracy to support their experimentation with citizen juries. There was abundant evidence of actors connecting different meanings together to form something new, as when the fossil fuel divestment movement blended meanings of social justice and morality attached to past divestment campaigns with meanings derived from climate science. Finally, we saw the work done in performing or delivering meaning in a form and context that is more likely to appeal to an audience and lead to uptake of those meanings. This work of performance was clearest in Bill McKibben's use of Rolling Stone, an international speaking tour and a simple story about a complex issue to reach his audience.

Like Zilber (2009), we observed movement of meanings across scales. NSC drew on a broader narrative of democratic innovation to legitimize its local decision to establish community juries, and then carried meanings generated by the participants up to the larger governance scale of the Queensland Government. The fossil fuel divestment movement began at a single college campus where students hit on the idea of connecting to societal meanings associated with divestment. The movement shifted to a global scale as a result of meaning work by Bill McKibben and others to establish a societal meta-narrative and carry it out to other contexts. Now, this meta-narrative is translated into local action through individual acts of divestment or campaigns to pressure organisations to divest. Our cases confirm Zilber's contention that there is a cyclic relationship between scales of narrative. Societal meta-narratives and the narratives that underpin and constrain specific institutions are constantly shifting and responding to each other. 
We also observed the interplay of agency and structure in both cases. Actors sourced meanings from their discursive context and combined them in novel ways to do work. In this sense, discursive structure was enabling. The existing story-line of "local democracy" in Noosa provided NSC and NDF with a platform for introducing an institutional innovation, while the discursive history of divestment carried meanings of morality and agency which offered activists a new approach to climate change response. On the other hand, discursive structure also constrains. NSC could not extricate itself from the story-line created through the de-amalgamation campaign without political damage, making an innovative approach to community engagement essential. Divestment campaigners are now constrained by a discourse that takes the current structure of the capitalist system as given, blunting more radical critiques.

Importantly, the concept of meaning work, especially the idea of discursive layers (Healey 1999; Healey et al. 2003), helped to explain the degree of institutional change that was evident in the cases. It is fair to say that neither of the cases shook up the meanings embedded in deeper governance relations. In Noosa, a more radical narrative of democratic innovation prompted some changes in institutional practice but was accommodated without deeper change to the nature of local democratic institutions. It is perhaps unreasonable to expect that a single local initiative could achieve such change. It is more likely that such change would come through the cumulative weight of many local initiatives, connected up to develop a compelling narrative for democratic reform. As the first attempt at citizen juries in Queensland, the Noosa case could not yet offer such a narrative.

In the fossil fuel divestment case, there was evidence that the divestment narrative is affecting systems of meaning about investment policy but little evidence of deeper discursive changes. Here, it may be what is missing from the narrative that limits 
its potential for institutional change. The focus of divestment campaigners is on undermining and disrupting existing institutions. They have been less vocal about the new institutions that will need to take their place, and indeed, what institutions should be maintained. To achieve deeper change, perhaps a more complete narrative that includes a tangible vision of success would be needed. These are ideas that could be tested in future research.

\section{Conclusion: Lessons for environmental governance}

Meaning work is diverse and context-dependent but our conceptual and empirical work highlighted some strategies for working with meanings that may be of value to environmental governance scholars and practitioners. Meaning work happens in a contested space. Actors deploy narratives and counter-narratives in a constant struggle to meet their diverse objectives. For environmental governance practitioners, meaning work most often involves disrupting existing institutions and creating new institutions, as current institutions are not sufficient to respond effectively to environmental challenges. In this context, Fligstein and McAdam's (2012) theory of fields is valuable, particularly their concept of social skill.

Fligstein and McAdam $(2012,46)$ define social skill as "the ability to induce cooperation by appealing to and helping to create shared meanings and collective identities". In any field, there will be challengers seeking change and incumbents resisting that change. Both can engage in meaning work as one tactic to either disrupt or defend institutions. Socially skilled actors are good at crafting ideational resources and recruiting other actors into their narratives. They have particular qualities that environmental governance practitioners could cultivate. They are empathetic, able to read the context and audience well, find common ground with the audience, frame lines of action, mobilise people and transcend their own individual interests (Fligstein and 
McAdam 2012). They are likely to be skilled "performers" of narrative, drawing on principles of rhetoric (see Walsh 2016; Dryzek and Lo 2015) and their reading of the context to deliver stories that build up "mutual understanding between speaker and listener" (Paschen and Ison 2014, 1084). They use stories to make connections that will support the institutions that they hold dear, whether existing or imagined. Our cases pointed to two distinct strategies employed by skilled meaning workers.

First, skilled meaning workers craft and perform compelling stories to recruit actors to their cause and mobilise discourse coalitions around new institutions. They draw liberally on the discursive context - reworking, rewriting and connecting existing meanings from other scales and places to create stories that suit their purposes. There is no shortage of advice on the construction of compelling stories (Simmons 2006; Cron 2012; Gottschall 2012; Walsh 2016; ACF 2017). Key elements include establishing trust, building a clear plot with a logical flow from cause to effect, showing what is at stake, identifying heroes and villains, and giving the audience agency by showing them how to play a role to achieve a clear goal. Stories cut through complexity by simplifying reality and using symbols to condense meanings down to what really matters. Bill McKibben's work to widely deploy the fossil fuel divestment narrative using wellestablished narrative tropes (e.g. heroes and villains) and a simple slogan of "unburnable carbon" is an excellent example. Of course, it is crucial that the meanings embedded in the story will appeal to the audience, which implies having a good understanding of that audience, how they can contribute to environmental governance, and where to reach them.

Second, skilled meaning workers identify and take advantage of narrative openings to disrupt and create institutions. Fligstein and McAdam (2012) point out that social skill and good stories alone are rarely sufficient to bring about institutional 
change, as both incumbents and challengers generally have access to similar amounts of social skill. For them, institutional change comes about when fields are disrupted, usually by events in proximate fields, creating an opportunity for challengers to exploit. In Noosa, the aftermath of the de-amalgamation campaign provided an opening for NDF and NSC to experiment with institutionalising citizen juries. In the case of fossil fuel divestment, the failure to achieve a binding international agreement on climate change in Copenhagen created an opening for a new kind of campaign. An important part of meaning work is timing - being able to deploy narratives at a time when they have genuine potential to take advantage of disruption and trigger desired institutional changes.

A final observation is that skilled meaning work involves striking a delicate balance between having meanings heard and providing enough provocation to drive change. Constant contestation over meanings and routine institutional work to maintain institutions means that new meanings are readily accommodated into the surface discourse of established institutions without achieving deeper discursive change. Meanings that are too alien to an institutional discourse may be rejected outright, while meanings that are closely aligned will not be transformative. There is an art in identifying opportunities to deploy meanings that provide just the right amount of challenge to trigger institutional change.

There is clearly a role for environmental governance practitioners to more consciously apply insights from institutional theory to engage in meaning work. Meaning work is a particularly accessible form of institutional work, requiring few material or legal resources. Creating new narratives is something that anybody can do. Further, it takes many forms that may suit different actors, including circulating societal meta-narratives like fossil fuel divestment, doing the local work of translating and 
weaving together stories to meet a specific local environmental governance need, and promoting local achievements that can contribute to the ever-changing meta-narratives. What remains unclear from our cases is how to create compelling meta-narratives that can successfully build discourse coalitions to shift deeper cultural reference points. Such work is likely required to resolve major environmental governance challenges and would be an appropriate focus for further research.

\section{References}

ACF. 2017. How to Tell Compelling Stories That Move People to Action. Carlton, Victoria: Australian Conservation Foundation. https://www.acf.org.au/narrative_handbook.

Ansar, Atif, Ben Caldecott, and James Tilbury. 2013. Stranded Assets and the Fossil Fuel Divestment Campaign: What Does Divestment Mean for the Valuation of Fossil Fuel Assets? Oxford: Smith School of Enterprise and the Environment, University of Oxford. http://www.smithschool.ox.ac.uk/researchprogrammes/stranded-assets/SAP-divestment-report-final.pdf.

Ayling, Julie, and Neil Gunningham. 2015. "Non-State Governance and Climate Policy: The Fossil Fuel Divestment Movement.” Climate Policy 3062 (98):1-15.

Battilana, Julie, and Thomas D'Aunno. 2009. "Institutional Work and the Paradox of Embedded Agency.” In Institutional Work: Actors and Agency in Institutional Studies of Organizations, edited by Thomas B. Lawrence, Roy Suddaby, and Bernard Leca, 31-58. Cambridge: Cambridge University Press.

Beunen, R, and J J Patterson. 2016. “Analysing Institutional Change in Environmental Governance: Exploring the Concept of 'Institutional Work." Journal of 
Environmental Planning and Management.

https://doi.org/10.1080/09640568.2016.1257423.

Biermann, Frank. 2007. “'Earth System Governance’ as a Crosscutting Theme of Global Change Research.” Global Environmental Change 17:326-37.

Biermann, Frank, Michele M. Betsill, Joyeeta Gupta, Norichika Kanie, Louis Lebel, Diana Liverman, Heike Schroeder, and Bernd Siebenhüner. 2009. Earth System Governance: People, Places and the Planet. Science and Implementation Plan of the Earth System Governance Project. Bonn: International Human Dimensions Programme on Global Environmental Change. https://doi.org/10.1787/9789264203419-101-en.

Bratman, Eve, Kate Brunette, Deirdre C. Shelly, and Simon Nicholson. 2016. "Justice Is the Goal: Divestment as Climate Change Resistance.” Journal of Environmental Studies and Sciences 6 (4):677-90. http://dx.doi.org/10.1007/s13412-016-0377-6.

Carbon Tracker Initiative. 2011. Unburnable Carbon - Are the World's Financial Markets Carrying a Carbon Bubble? London: Carbon Tracker Initiative. https://doi.org/10.1108/meq.2013.08324eaa.003.

Chaffin, Brian C., Ahjond S. Garmestani, Lance H. Gunderson, Melinda Harm Benson, David G. Angeler, Craig Anthony (Tony) Arnold, Barbara Cosens, Robin Kundis Craig, J.B. Ruhl, and Craig R. Allen. 2016. "Transformative Environmental Governance." Annual Review of Environment and Resources 41 (1):399-423. https://doi.org/10.1146/annurev-environ-110615-085817.

Cron, Lisa. 2012. Wired for Story. New York: Ten Speed Press. 
Czarniawska, Barbara. 2014. A Theory of Organizing. 2nd ed. Cheltenham, UK and Northampton, USA: Edward Elgar.

David, Robert J., Wesley D. Sine, and Caroline Kaehr Serra. 2017. "Institutional Theory and Entrepreneurship: Taking Stock and Moving Forward.” In The SAGE Handbook of Organizational Institutionalism, edited by R. Greenwood, C. Oliver, T. Lawrence, and R. Meyer, 671-88. SAGE Publications Ltd.

Dryzek, John S., and Alex Y. Lo. 2015. "Reason and Rhetoric in Climate Communication.” Environmental Politics 24 (1):1-16. https://doi.org/10.1080/09644016.2014.961273.

Fligstein, Neil, and Doug McAdam. 2012. A Theory of Fields. New York: Oxford University Press.

Gardner, Claire. 2015. “ANU Partial Fossil Fuel Divestment Had 'significant Positive Financial Impact."” Fossil Free ANU. 17 November. https://fossilfreeanu.wordpress.com/2015/11/17/anu-partial-fossil-fuel-divestmenthad-significant-positive-financial-impact/.

Giddens, Anthony. 1984. The Constitution of Society: Outline of the Theory of Structuration. Cambridge: Polity Press.

Gottschall, Jonathan. 2012. The Storytelling Animal : How Stories Make Us Human. New York: Houghton Mifflin Harcourt.

Grady-Benson, Jessica, and Brinda Sarathy. 2016. "Fossil Fuel Divestment in US Higher Education: Student-Led Organising for Climate Justice.” Local Environment 21 (6):661-81. https://doi.org/10.1080/13549839.2015.1009825. 
Hajer, Maarten A. 1995. The Politics of Environmental Discourse: Ecological Modernization and the Policy Process. Oxford: Clarendon Press.

Hampel, Christian E., Thomas B. Lawrence, and Paul Tracey. 2017. "Institutional Work: Taking Stock and Making It Matter.” In The SAGE Handbook of Organizational Institutionalism, edited by Royston Greenwood, Christine Oliver, Thomas B. Lawrence, and Renate E. Meyer, 558-90. SAGE Publications Ltd.

Healey, Patsy. 1999. "Sites, Jobs and Portfolios : Economic Development Discourses in the Planning System." Urban Studies 36 (1):27-42.

Healey, Patsy, Claudio de Magalhaes, Ali Madanipour, and John Pendlebury. 2003. "Place, Identity and Local Politics: Analysing Initiatives in Deliberative Governance." In Deliberative Policy Analysis: Understanding Governance in the Network Society, edited by Maarten A. Hajer and Hendrik Wagenaar, 60-87. Cambridge: Cambridge University Press. https://doi.org/10.1017/CBO9780511490934.004.

Healy, Noel, and Jessica Debski. 2017. "Fossil Fuel Divestment: Implications for the Future of Sustainability Discourse and Action within Higher Education." Local Environment 22 (6):699-724. https://doi.org/10.1080/13549839.2016.1256382.

Hirtenstein, Anna. 2017. "Electricity Overtook Fossil Fuels in Push for Investment in 2016.” Bloomberg Markets. 11 July. https://www.bloomberg.com/news/articles/2017-07-11/electricity-overtook-fossilfuels-in-push-for-investment-in-2016.

Inayatullah, Sohail. 1998. "Causal Layered Analysis: Poststructuralism as Method." Futures 30 (8):815-29. 
Jackson, Tim. 2009. Prosperity without Growth: Economics for a Finite Planet. Milton Park: Earthscan.

Jasanoff, Sheila. 2015. "Future Imperfect: Science, Technology, and the Imaginations of Modernity." In Dreamscapes of Modernity: Sociotechnical Imaginaries and the Fabrication of Power, 1-33. https://doi.org/10.1007/s13398-014-0173-7.2.

Jotzo, Frank. 2014. "Outrage at ANU Divestment Shows the Power of Its Idea." The Conversation. 13 October. https://theconversation.com/outrage-at-anu-divestmentshows-the-power-of-its-idea-32736.

Lawrence, Thomas B., and Roy Suddaby. 2006. "Institutions and Institutional Work." In SAGE Handbook of Organization Studies, edited by Stewart R. Clegg, Cynthia Hardy, Thomas B. Lawrence, and Walter R. Nord, 2nd ed., 215-54. London: Sage. https://doi.org/10.2307/591759.

Lounsbury, Michael, and Mary Ann Glynn. 2001. "Cultural Entrepreneurship: Stories, Legitimacy, and the Acquisition of Resources.” Strategic Management Journal 22:545-64. https://doi.org/10.1002/smj.188.

Lowndes, Vivien, and Mark Roberts. 2013. Why Institutions Matter: The New Institutionalism in Political Science. New York: Palgrave Macmillan.

McKibben, Bill. 2012. “Global Warming’s Terrifying New Math.” Rolling Stone. 19 July. https://doi.org/10.1002/ece3.884.

_. 2013. “The Case for Fossil-Fuel Divestment.” Rolling Stone. 22 February. http://www.rollingstone.com/politics/news/the-case-for-fossil-fuel-divestment20130222. 
Meyer, John W., and Brian Rowan. 1977. “Institutionalized Organizations: Formal Structure as Myth and Ceremony." American Journal of Sociology 83 (2):340-63. https://doi.org/10.1086/226550.

newDemocracy Foundation. 2014. "Discussion Paper 2: Delivering Noosa Council a Democratic Process the Envy of Australia.” June. https://www.newdemocracy.com.au/docs/activeprojects/NoosaCouncil_newDemoc racy Process Paper_June2014.pdf.

Paschen, Jana Axinja, and Ray Ison. 2014. "Narrative Research in Climate Change Adaptation-Exploring a Complementary Paradigm for Research and Governance." Research Policy 43 (6):1083-92. https://doi.org/10.1016/j.respol.2013.12.006.

Patterson, James, Karsten Schulz, Joost Vervoort, Sandra van der Hel, Oscar Widerberg, Carolina Adler, Margot Hurlbert, Karen Anderton, Mahendra Sethi, and Aliyu Barau. 2017. "Exploring the Governance and Politics of Transformations towards Sustainability." Environmental Innovation and Societal Transitions 24:1-16. https://doi.org/10.1016/j.eist.2016.09.001.

Perkmann, Markus, and André Spicer. 2008. "How Are Management Fashions Institutionalized? The Role of Institutional Work." Human Relations 61 (6):81144. https://doi.org/10.1177/0018726708092406.

Phillips, Nelson, Thomas B. Lawrence, and Cynthia Hardy. 2004. "Discourse and Institutions." Academy of Management Review 29 (4):636-52. https://doi.org/10.5465/AMR.2004.14497617.

Polletta, Francesca, Pang Ching Bobby Chen, Beth Gharrity Gardner, and Alice Motes. 2011. “The Sociology of Storytelling.” Annual Review of Sociology 37 (1):109-30. 
https://doi.org/10.1146/annurev-soc-081309-150106.

Ruebottom, Trish. 2013. "The Microstructures of Rhetorical Strategy in Social Entrepreneurship: Building Legitimacy through Heroes and Villains.” Journal of Business Venturing 28 (1):98-116. https://doi.org/10.1016/j.jbusvent.2011.05.001.

Scott, W Richard. 2014. Institutions and Organizations: Ideas, Interests and Identities. 4th ed. Thousand Oaks: SAGE. https://doi.org/10.1016/S0263-2373(97)89895-7.

Shove, Elizabeth, Mika Pantzar, and Matt Watson. 2012. The Dynamics of Social Practice. London: SAGE.

Simmons, Annette. 2006. The Story Factor. Cambridge: Basic Books.

Strang, David, and John W. Meyer. 1993. "Institutional Conditions for Diffusion.” Theory and Society 22 (4):487-511. https://doi.org/10.1007/BF00993595.

Walsh, Lynda. 2016. "Understanding the Rhetoric of Climate Science Debates." Wiley Interdisciplinary Reviews: Climate Change, e452. https://doi.org/10.1002/WCC.452.

Zilber, Tammar B. 2009. “Institutional Maintenance as Narrative Acts.” In Institutional Work: Actors and Agency in Institutional Studies of Organizations, edited by Thomas B. Lawrence, Roy Suddaby, and Bernard Leca, 204-35. Cambridge: Cambridge University Press.

—. 2017. "The Evolving Role of Meaning in Theorizing Institutions." In The SAGE Handbook of Organizational Institutionalism, edited by Royston Greenwood, Christine Oliver, Thomas B. Lawrence, and Renate E. Meyer, 418-45. Thousand Oaks: SAGE. 
